\title{
The Effect of Indigenous Growth Media on Allanblackia parviflora A. Chev in Ghana
}

\author{
Edward Yeboah ${ }^{*}$, Daniel Aninagyei Ofori ${ }^{2,3}$, Theresa Peprah², \\ Ramni Harmanjeet Jamnadass ${ }^{3}$, Alain Tsobeng ${ }^{4}$ \\ ${ }^{1}$ CSIR-Soil Research Institute, Academy Post Office, Kumasi, Ghana \\ ${ }^{2}$ CSIR-Forestry Research Institute of Ghana, University Post Office, KNUST, Kumasi, Ghana \\ ${ }^{3}$ World Agroforestry Centre, Nairobi, Kenya \\ ${ }^{4}$ World Agroforestry Centre, Yaoundé, Cameroon \\ Email: "eyeboah5@hotmail.com
}

Received 25 September 2015; accepted 27 May 2016; published 30 May 2016

Copyright (C) 2016 by authors and Scientific Research Publishing Inc.

This work is licensed under the Creative Commons Attribution International License (CC BY).

http://creativecommons.org/licenses/by/4.0/

(c) (i) Open Access

\begin{abstract}
Allanblackia parviflora A. Chev. also called vegetable tallow tree provides a variety of non-timber forest products of great importance to rural households including shade, timber, medicine and seed oil but attempts have not been made to improve the tree species and increase its production. Consequently, the species is being threatened due to unsustainable exploitation and poor regeneration and cultivation appears as the only viable option. In order to cultivate the species at meaningful scale, it is necessary to establish the optimum range of environmental factors that influence its propagation and growth. This study was therefore designed to investigate Allanblackia growth parameters and bio-accumulation under different growth media in a greenhouse study. The media were: 1) TS = top soil alone, 2) AB soil = Allanblackia soil alone, 3) $\mathrm{TS}+\mathrm{H}=$ Top soil alone + humus, 4) AB + TS = Allanblackia soil alone + Top soil alone and 5) SAB = Sterilized Allanblackia soil alone. Each treatment was replicated three times in a complete randomized design. The experiment lasted for 18 months. Results showed that Fe was the micronutrient that accumulated greatest in the plant tissue. Among the treatments, Allanblackia soil showed the highest accumulation of $\mathrm{Zn}$ in the plant tissue with the top soil showing the least $\left(7.67 \mathrm{mg} \cdot \mathrm{kg}^{-1}\right)$. Humus contributed largely to the bio-accumulation of $\mathrm{Cu}$ in the plant tissue. Bio-accumulation of manganese in the plant tissue ranged from $13.30 \mathrm{mg} \cdot \mathrm{kg}^{-1}$ to $207 \mathrm{mg} \cdot \mathrm{kg}^{-1}$ suggesting difference in manganese absorption by Allanblackia as influenced by the treatments. The growth parameters of Allanblackia parviflory were impacted differently by the growth media. The result was however controversial since no differences were found between growth of seedlings in sterilized Allanblackia soil and Allanblackia soil.
\end{abstract}

${ }^{*}$ Corresponding author.

How to cite this paper: Yeboah, E., Ofori, D.A., Peprah, T., Jamnadass, R.H. and Tsobeng, A. (2016) The Effect of Indigenous Growth Media on Allanblackia parviflora A. Chev in Ghana. Open Journal of Soil Science, 6, 89-97.

http://dx.doi.org/10.4236/ojss.2016.65010 


\section{Keywords}

\section{Allanblackia, Bio-Accumulation, Growth Media, Mycorrhiza}

\section{Introduction}

Allanblackia parviflora A. Chev. also called vegetable tallow tree belongs to the family of Clusiaceae (Gutiferae). It is a medium-sized tree that grows to a height of about $40 \mathrm{~m}$. The bole is cylindrical or slightly fluted, rarely greater than $50 \mathrm{~cm}$ diameter at breast height (DBH) with narrow crown of horizontal branches with large leaves, which have shiny surfaces and numerous lateral nerves forked near the margins. The bark is reddishbrown with small rectangular or circular scales over small red pits (Hawthorne, 1990 [1]; Hawthorne and Gyakari, 2006 [2]).

The distribution zone of the species ranges from Sierra Leone through Liberia and Cote D'Ivoire to Ghana. The species provides a variety of non-timber forest products of great importance to rural households including shade, timber, medicine and seed oil. The kernel when dried contains about 67 - 73 percent of solid white fat (Siaw et al., 2003 [3], Sefah, 2006 [4]). Traditionally oil extracted from the seed has been used locally for cooking and soap making (Ofori et al., 2006 [5]; Irvine, 1961 [6]), with the most economical importance being edible fat used for cooking and manufacture of margarine. The development of its value chain is still ongoing and in 2006, Ghana exploited about 50 tons of oil

(http://www.prota4u.org/protav8.asp?fr=1\&g=pe\&p=Allanblackia+parviflora+A.Chev).

A. parviflora despite its socio-economic, medicinal and cultural importance has suffered a neglect in the area of research and development. In Ghana, several rural micro enterprises have been established but attempts have not been made to improve the tree species and increase its production. Consequently, the species is being threatened due to unsustainable exploitation and poor regeneration so that only $5 \%$ of the seed demand is supplied with a consequence of reduction of beneficiaries. To offset this imminent threat of extinction and to meet increasing demand, cultivation appears as the only viable option (Leakey, 2001 [7]). However, in order to cultivate the species at any meaningful scale, it is necessary to establish the optimum range of environmental factors that influence its propagation and growth. In terms of propagation, several studies have been conducted (Ofori et al., 2011 [8]; Ofori et al., 2008 [9]; Peprah et al., 2009 [10]) describing seed germination and grafting. Despite getting adequate seed germination, subsequent growth of the seedlings has not been encouraging due to yellowing of leaves observed after three months of potting of seedlings. Among factors stimulating tree growth in the nursery, improving the substrate fertility and absorption potential of roots by mycorrhizal inoculation can be cited (Brown and Van Den Driessche, 2005 [11]). It should be noted that the presence of soil nutrients does not necessarily mean that absorption can take place unless there is sufficient development of the root system for nutrient uptake. Wildlings growing under the mother trees were found to be growing well. A preliminary cursory study also showed that seedlings grown in soil collected from the mother tree grew well without yellowing of leaves. Examination of the root system of A. parviflora revealed a main tap root with poor fibrous root system. Nonetheless, plants with poor fine roots extension like Allanblackia grow very slowly (Swift, 1998 [12]). Improved underground conditions for the young plants through improved root dynamics can therefore be beneficial to greater survival and/or improved establishment during the initial period after planting (Brundrett, 1996 [13]). Experience suggests that absorption potential of host plants could be improved through mycorrhizal innoculation (Brundrett, 1996 [13]). This is further supported by other studies that have highlighted the positive effect of mycorrhizal inoculation on growth of host plants including Senna siamea (Bhoopander et al., 2005 [14]), Acacia senegal (Sarr et al., 2005 [15]), Lophira alata and Pterocarpus soyauxii (Onguene et al., 2011 [16]). The symbiotic relationship between the host's roots and the fungus is based on the fact that the fungus receives carbohydrates from the host, while the host's absorption potential of water and nutrients is improved by means of the hyphae produced by the fungus from the root to the soil (Smith and Read, 1997 [17]). The hyphae extend to 8 $\mathrm{cm}$ from host plant roots and thus, increase the surface area of the root system for efficient uptake of water and nutrients. This study was therefore designed to investigate Allanblackia in soil collected from Allanblackia tree in the presence of mycorrhiza or other chemical composition. 


\section{Methodology}

\subsection{Study Site}

The experiment was carried out in a greenhouse of Council for Scientific and Industrial Research-Forestry Research Institute of Ghana (CSIR-FORIG) located in Kumasi, Ghana $\left(6^{\circ} 40^{\prime} \mathrm{N}, 1^{\circ} 40^{\prime} \mathrm{W}\right)$. The site falls within the Semi-deciduous forest zone of Ghana with a bimodal rainfall pattern. This involves two peaks which generally occur from May to June and September to October. Usually there is a brief dry period in August. The major dry period starts from December and ends in March. Annual rainfall is about $1200 \mathrm{~mm}$ and a temperature range of about $22.1^{\circ} \mathrm{C}-31.3^{\circ} \mathrm{C}$.

\subsection{Experimental Design and Management Practices}

Uniform sized seeds of Allanblackia parviflora were potted in poly bags of sizes $25 \mathrm{~cm} \times 25 \mathrm{~cm}$ in five different media. The media were: 1) TS = top soil alone, 2) $\mathrm{AB}$ soil = Allanblackia soil alone, 3) $\mathrm{TS}+\mathrm{H}=\mathrm{Top}$ soil alone + humus, 4) $\mathrm{AB}+\mathrm{TS}=$ Allanblackia soil alone + Top soil alone and 5) Sterilized AB = Sterilized Allanblackia soil alone. The AB soil was collected from Samereboi within the Allanblackia growing zone with average annual rainfall of $\geq 1750 \mathrm{~mm}$. Top soil from 0 - $15 \mathrm{~cm}$ depth was also collected from Kumasi where no Allanblackia tree was growing. Sterilisation of soil was done by heating soil in pan on fire for 30 minutes at a temperature of $82^{\circ} \mathrm{C}$. Ten seedlings were allocated to each medium. Seedlings were arranged in the greenhouse in randomized complete block design with three replications. Seedlings were watered daily to field capacity to ensure water is not limiting plant growth as the plant ages. Emerging weeds were handpicked from the pots regularly to avoid competition with the plants. Baseline data were taken at one week after potting and then 18 months after potting. Plant height was measured with a meter rule from the soil surface to the tip of the plant, root collar diameter was measured using a digital caliper and the number of leaves produced was recorded. The duration of the experiment was for 18 months. Destructive samples were also taken at 18 months after potting for plant nutrient analysis. At harvest, Allanblackia plant shoot were weighed and oven dried at $60^{\circ} \mathrm{C}$. The oven dried samples were ground and sieved through a 2-mm mesh size.

\section{Plant Nutrient Analysis}

Total $\mathrm{N}$ and $\mathrm{P}$ in Allanblackia samples were determined from micro-Kjeldahl digests with $\mathrm{H}_{2} \mathrm{SO}_{4}$ and $\mathrm{H}_{2} \mathrm{O}_{2}$ by steam distillation and titration with $\mathrm{HCl}$ for $\mathrm{N}$ and by colorimetry (molybdenum-blue) for $\mathrm{P}$.

\subsection{Soil Analyses}

Soil pH was measured in soil to water ratio of 1:1 (Mclean, 1982 [18]). The Walkley Black procedure was used to determine soil organic carbon (Walkley and Black, 1934 [19]). Total nitrogen (N) was determined using the Kjedahl digestion and distillation procedure. The cation exchange capacity (CEC) at $\mathrm{pH} 7$ was determined by the $\mathrm{NH}_{4} \mathrm{OAc}$ method. Calcium (Ca) and Magnesium (Mg) were determined by atomic absorption spectrophotometry while potassium $(\mathrm{K})$ and sodium $(\mathrm{Na})$ were determined by flame photometry. The effective cation exchange capacity (ECEC) was determined as the sum of exchangeable cations and exchangeable acidity. Exchangeable acidity $\left(\mathrm{H}^{+}\right.$and $\left.\mathrm{Al}^{3+}\right)$ was extracted with $1 \mathrm{M} \mathrm{KCl}$ and determined by titration with $\mathrm{NaOH}$ before and after addition of NaF (Sims, 1996 [20]). Available phosphorus was determined using Bray No. I extraction solution (Bray and Kurtz, 1945 [21]). Heavy metals were determined in 0.5 M EDTA soil extract on atomic absorption spectrophotometer model VGL Buck scientific.

\section{Statistical Analysis}

The effects of treatments on Allanblackia yield indices, soil chemical properties were determined using GenStat $^{\circledR}$ (2007) and an ANOVA procedure (Payne et al. 2006 [22]). Individual comparisons between treatments were performed using least significance difference (lsd) at $0.05 \%$.

\section{Results}

Table 1 shows the soil chemical properties of the treatments. Soil $\mathrm{pH}$ ranged from 3.8 to 6.5. Addition of Humus increased the top soil (TS) $\mathrm{pH}$ by 0.8 units. The Allanblackia soil was acidic $(\mathrm{pH}=3.8)$ and increased in $\mathrm{pH}$ (0.4 units) with sterilization. Most interestingly, addition of topsoil to the Allanblackia soil resulted in a significant 
increase in the $\mathrm{pH}(0.37$ units $)$ of the Allanblackia soil. The $\mathrm{pH}$ of the treatments was significantly different from each other $(\mathrm{p}<0.01)$.

There were significant differences $(\mathrm{p}<0.05)$ in the soil organic carbon content among the different media with the least observed in the top soil (0.55\%) and the highest in the Allanblackia soil (2.4\%). Addition of humus to the top soil resulted in a three-fold increase in soil organic carbon content of the mixture. Sterilization of the Allanblackia soil however, resulted in $14 \%$ decrease in soil organic carbon while addition of top soil resulted in 37\% decrease in Allanblackia soil organic carbon.

The low total $\mathrm{N}$ of the TS (0.09) is accounted for by the low organic carbon content; an indicative of soil fertility decline in the top soil (Lal, 1983 [23]). This could be explained by loss of top soil nutrients through continuous cropping and absence of soil cover resulting in erosion. Addition of humus to the topsoil and sterilization of the Allanblackia soil showed $56 \%$ and $12 \%$ increases in total soil $\mathrm{N}$ respectively. Addition of topsoil to mother soil however, caused $41 \%$ decline in total soil $\mathrm{N}$ of the Allanblackia soil. The decline in soil $\mathrm{N}$ could impact on nutrient availability for plant growth with plants showing symptoms of nitrogen deficiency.

The increase in Total Exchangeable Bases (TEB) with addition of humus is not unexpected. Addition of humus adds free bases such as $\mathrm{Ca}, \mathrm{Mg}, \mathrm{Na}$ and thus increasing the $\mathrm{pH}$ of the soil and providing readily available soil nutrients for plant growth. Humus has high TEB and it is reasonable that soil amended with humus has high TEB. This may account for the corresponding increase in $\mathrm{pH}$ of the TS $+\mathrm{H}$ treatment. The exchange sites of the soils were dominated by $\mathrm{Ca}$ and $\mathrm{Mg}$. The low exchangeable bases of the mother soil account for the high exchangeable acidity as well as the low base saturation of the Allanblackia soil. It is necessary to improve the nutrient content of the soil through addition of humus for sustained growth.

The elemental concentration of the Allanblackia tissue after harvesting is presented in Table 2. Elemental Ca ranged from $1.34 \%$ on the sterilized Allanblackia soil to $1.92 \%$ on the topsoil + humus treatment. Humus addition contributed $18.5 \%$ more in Ca concentration in the plant tissue relative to the topsoil. Sterilization resulted in $11 \%$ decline in \% Ca concentration relative to the Allanblackia soil but was not statistically different from the

Table 1. Soil chemical properties of the treatments.

\begin{tabular}{|c|c|c|c|c|c|c|c|c|c|c|c|c|c|c|c|c|c|}
\hline \multirow{2}{*}{ Treatments } & \multirow{2}{*}{$\begin{array}{c}\mathrm{pH} \\
\mathrm{H}_{2} \mathrm{O}\end{array}$} & \multirow{2}{*}{$\underset{\%}{\operatorname{Org} C}$} & \multirow{2}{*}{$\begin{array}{l}\mathrm{N} \\
\%\end{array}$} & $\mathrm{Ca}$ & $\mathrm{Mg}$ & K & $\mathrm{Na}$ & TEB & \multirow{2}{*}{$\begin{array}{c}\text { Ex. } \\
\text { Acidity }\end{array}$} & \multirow{2}{*}{$\begin{array}{c}\text { ECEC } \\
\mathrm{Cmol}^{(+)} \\
\mathrm{kg}^{-1}\end{array}$} & \multirow{2}{*}{$\begin{array}{c}\text { Base Sat } \\
\%\end{array}$} & \multirow{2}{*}{$\begin{array}{l}\text { Av. P } \\
\text { ppm }\end{array}$} & \multirow{2}{*}{$\begin{array}{c}\text { Av. K } \\
\text { ppm }\end{array}$} & $\mathrm{Zn}$ & $\mathrm{Cu}$ & $\mathrm{Fe}$ & Mn \\
\hline & & & & & cmo & ol (+) & $\mathrm{kg}^{-1}$ & & & & & & & \multicolumn{4}{|c|}{ ppm } \\
\hline TS & 5.77 & 0.55 & 0.09 & 2.31 & 0.78 & 0.19 & 0.12 & 3.40 & 0.42 & 3.81 & 89.03 & 31.99 & 91.63 & 0.77 & 0.14 & 10.70 & 18.50 \\
\hline $\mathrm{TS}+\mathrm{H}$ & 6.50 & 1.74 & 0.14 & 7.65 & 1.52 & 0.39 & 0.17 & 9.73 & 0.12 & 9.85 & 98.81 & 62.95 & 100.43 & 2.32 & 1.70 & 13.36 & 17.00 \\
\hline $\mathrm{AB}$ & 3.80 & 2.41 & 0.17 & 1.10 & 0.81 & 0.20 & 0.13 & 2.23 & 1.42 & & 61.19 & 16.39 & 103.78 & 44.58 & 0.84 & 172.73 & 3.23 \\
\hline SAB & 4.20 & 2.08 & 0.19 & 1.25 & 0.89 & 0.22 & 0.11 & 2.47 & 0.93 & 3.41 & 72.46 & 32.10 & 130.76 & 16.00 & 0.54 & 154.57 & 8.17 \\
\hline $\mathrm{AB}+\mathrm{TS}$ & 4.57 & 1.51 & 0.10 & 2.11 & 0.96 & 0.22 & 0.11 & 3.40 & 0.82 & 4.21 & 80.57 & 32.63 & 102.11 & 47.33 & 0.78 & 77.50 & 15.83 \\
\hline $\mathrm{CV} \%$ & 3.6 & 5.4 & 7.8 & 7.2 & 11.1 & 9.1 & 17.7 & 5.3 & 4.9 & 41 & 2.2 & 2.8 & 3.3 & 5.4 & 7.3 & 3.7 & 7.1 \\
\hline Lsd (0.05) & 0.32 & 0.16 & 0.02 & 0.38 & 0.20 & 0.04 & 0.04 & 0.41 & 0.07 & 0.37 & 3.20 & 1.81 & 6.41 & 2.20 & 0.11 & 5.81 & 1.63 \\
\hline
\end{tabular}

TS-Top soil alone, TS + H-Top soil alone + Humus, AB-Allanblackia soil alone, Sterile AB-Sterilized Allanblackia soil alone, AB + TS-Allanblackia soil alone + Top soil alone.

Table 2. Concentration of selected nutrients in the Allanblackia plant tissue.

\begin{tabular}{|c|c|c|c|c|c|c|c|c|c|}
\hline Treatments & $\mathrm{Ca} \%$ & $\mathrm{Mg} \%$ & P \% & K \% & $\mathrm{N} \%$ & $\mathrm{Fe} \mathrm{mg} / \mathrm{Kg}$ & $\mathrm{Zn} \mathrm{mg/Kg}$ & $\mathrm{Cu} \mathrm{mg} / \mathrm{Kg}$ & $\mathrm{Mn} \mathrm{mg} / \mathrm{Kg}$ \\
\hline TS & 1.62 & 0.20 & 0.13 & 0.48 & 1.10 & 164.00 & 7.67 & 2.57 & 25.00 \\
\hline $\mathrm{TS}+\mathrm{H}$ & 1.92 & 0.24 & 0.13 & 0.59 & 1.38 & 77.30 & 12.33 & 82.00 & 15.30 \\
\hline $\mathrm{AB}$ & 1.51 & 0.25 & 0.11 & 0.49 & 1.40 & 59.00 & 17.67 & 6.13 & 207.00 \\
\hline SAB & 1.34 & 0.22 & 0.10 & 0.52 & 1.47 & 59.00 & 11.00 & 6.13 & 137.00 \\
\hline $\mathrm{AB}+\mathrm{TS}$ & 1.55 & 0.22 & 0.12 & 0.56 & 1.63 & 121.70 & 12.00 & 6.90 & 95.7 \\
\hline $\mathrm{CV} \%$ & 13.1 & 35.7 & 20.0 & 9.6 & 10.8 & 12.60 & 12.20 & 10.20 & 13.0 \\
\hline Lsd (0.05) & 0.38 & 0.15 & 0.04 & 0.09 & 0.27 & 22.08 & 2.70 & 3.84 & 22.66 \\
\hline
\end{tabular}

TS—Top soil, TS + H—Top soil + Humus, AB—Allanblackia soil, SAB—Sterilized Allanbalcakia soil, AB + TS—Allanblackia soil + Top soil . 
Allanblackia soil + top soil. Elemental magnesium varied narrowly across the treatments and ranged from $0.20 \%$ to $0.25 \%$. The differences in the Mg concentration were not significantly different across the treatments. Phosphorus content ranged narrowly $0.10 \%$ to $0.13 \%$ and was statistically similar across treatments. The elemental $\mathrm{K}$ showed that TS + Humus was significantly different from the Allanblackia soil again emphasizing the contribution of in improving the $\mathrm{K}$ nutrition of Allanblackia. There was a synergistic effect in increasing $\mathrm{N}$ content of the plant tissue by combining the Allanblackia soil and top soil (TS).

The relationship between soil chemical content and plant tissue chemical content is shown in Figure 1. The highest accumulation of Fe was observed at the top soil treatment with the Allanblackia soil and sterilized Allanblackia soil showing the same Fe accumulation. Sterilization did not affect Fe accumulation in the Allanblackia tissue. The addition of the Allanblackia soil to the top soil i.e. AB + TS resulted in $26 \%$ decline in the accumulation of Fe in the plant tissue. Iron was the micronutrient that accumulated greatest in the plant tissue. The Allanblackia soil on the other hand, showed the highest accumulation of $\mathrm{Zn}$ in the plant tissue with the top soil showing the least $\left(7.67 \mathrm{mg} \cdot \mathrm{kg}^{-1}\right)$. The high $\mathrm{Cu}$ accumulation in the TS $+\mathrm{H}$ treatment and the low accumulation of $\mathrm{Cu}$ under the TS treatment suggest that the humus contributed largely to the bioaccumulation of $\mathrm{Cu}$ in the plant tissue. Bio-accumulation of manganese in the plant tissue ranged from $13.30 \mathrm{mg} \cdot \mathrm{kg}^{-1}$ to $207 \mathrm{mg} \cdot \mathrm{kg}^{-1} \mathrm{sug}-$ gesting difference in manganese absorption by the plant as influenced by the treatment.

\section{Plant Growth Indices}

The plant height of Allanblackia at harvest is shown in Figure 2. Plant growth was influenced by the media used. The sterilized Allanblackia soil and the Allanblackia soil promoted the highest growth of Allanblackia with the Humus + top soil treatment medium showing the least growth. The diameter of Allanblackia seedling as influenced by the different media is shown in Figure 3. The diameter ranged narrowly between $5 \mathrm{~mm}$ and $6.4 \mathrm{~mm}$ without showing any significant differences $(p>0.05)$ among treatments. The number of leaves per plant also varied significantly ( $\mathrm{p}<0.05)$ and ranged from $12(\mathrm{AB}+\mathrm{TS})$ to $15(\mathrm{H}+\mathrm{TS})$ (Figure 4). The amount of chlorophyll in leaves also varied significantly $(\mathrm{p}<0.05)$ and followed a similar trend as that of height growth. Generally, seedlings grown in $100 \%$ Allanblackia soil (AB) had higher chlorophyll content than other media (Figure 5).

\section{Discussion}

The study has shown the increase in $\mathrm{pH}$ of the Allanblackia soil through addition of the humus. This could be due to the high exchangeable cations in humus. The low $\mathrm{pH}$ of the Allanblackia soil on the other hand could be due to leaching of exchangeable cations as a result of the high rainfall commonly observed in the Western region of Ghana (Nye and D. Stephens, 1962 [24]). The observed lack of significant differences between seedlings grown on Allanblackia soil and Sterilized Allanblackia Soil comes up with two suggestions: 1) either Allanblackia growth is independent on mycorrhiza association or 2) sterililization of soil was incomplete. Taking into consideration of the acidic nature of soil within the Allanblackia growing zones and the lack of fibrous root system on Allanblackia seedlings, it may however be premature to conclude that Allanblackia growth is independent on mycorrhiza. Smith and Read (1997) [17] reported on the different types of symbiotic interactions between heterotrophs and autotrophs, where the plants get nutrients from fungi in exchange for carbohydrate (Plenchette et al., 1983 [25]; Sieverding, 1991 [26]; Brundrett, 1996 [13]). Hence factors affecting symbiotic microbe's efficiency need to be explored. Earlier studies have described the existence of different mycorrhizal strains and differences in their efficiency (Ngonkeu, 2003 [27]; Bhoopander et al. 2005 [14]). Furthermore, the duration of the observation period is an import factor for consideration. It has been established that root colonization takes place in millet and sorghum at two or three months after inoculation (Ngonkeu, 2003 [27]). Hence a new tree crop like Allanblackia might need to be observed for a much longer period.

In terms of mycorrhizas and soil chemical properties, Ngonkeu (2009) [28] demonstrated a strong correlation between arbuscular mycorrhizal efficiency and $\mathrm{pH}$ (water) and Aluminum of soil. Others have also obtained variable results in the relationship between mycorrhizal efficiency and chemical property of a soil (Newman et al. 1981 [29]; Motosugi et al., 2002 [30]; Isaac, 1992 [31]). Isaac (1992) [31] demonstrated that mycorrhizal efficiency increases with decreasing soil P content but no evidence of mycorrihzal and soil P content was found in the current study.

The high organic C content of the Allanblackia soil could be due to surface protection by the tree cover on the 

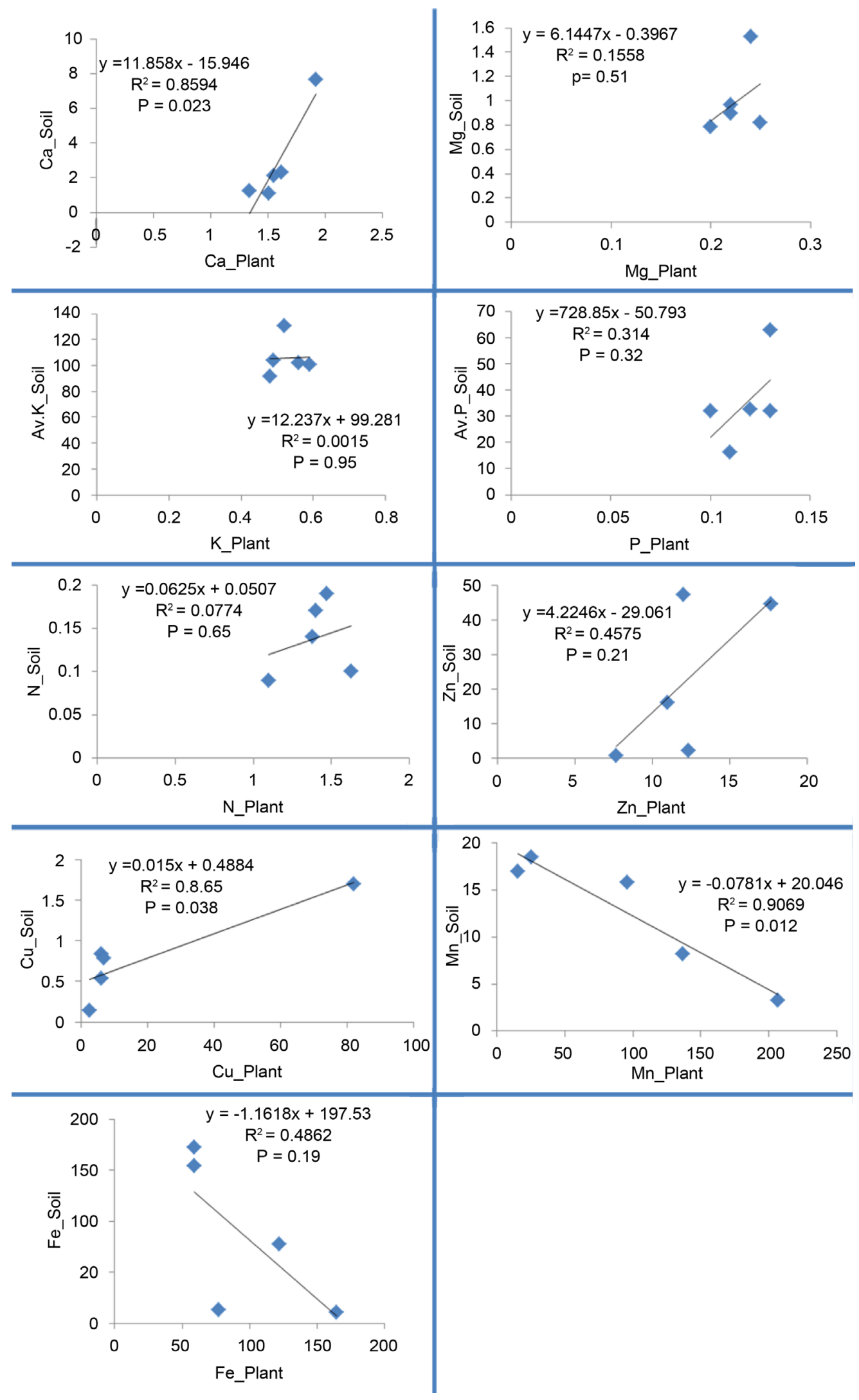

Figure 1. Pearson correlations between soil chemical content and plant tissues content. 
sampling site while accelerated mineralization of the organic matter may account for the low soil organic carbon of the TS (Tiessen et al. 1994 [32]; Zech et al., 1996 [33]).

\section{Conclusion}

Growth media comprising, top soil, Allanblackia soil, Allanblackia soil + top soil, top soil + humus, sterile Allanblackia soil were used to evaluate the yield indices, soil and plant chemical composition of Allanblackia

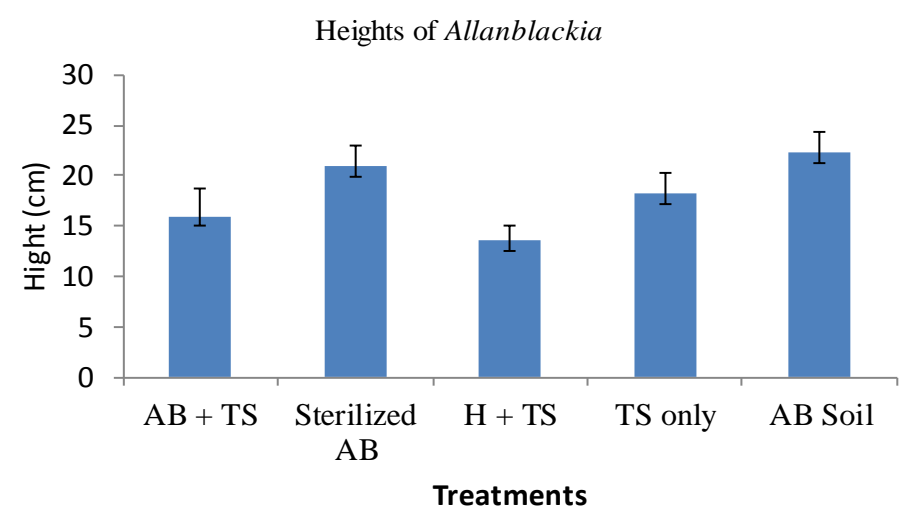

Figure 2. Effect of different media on plant height of Allanblackia.

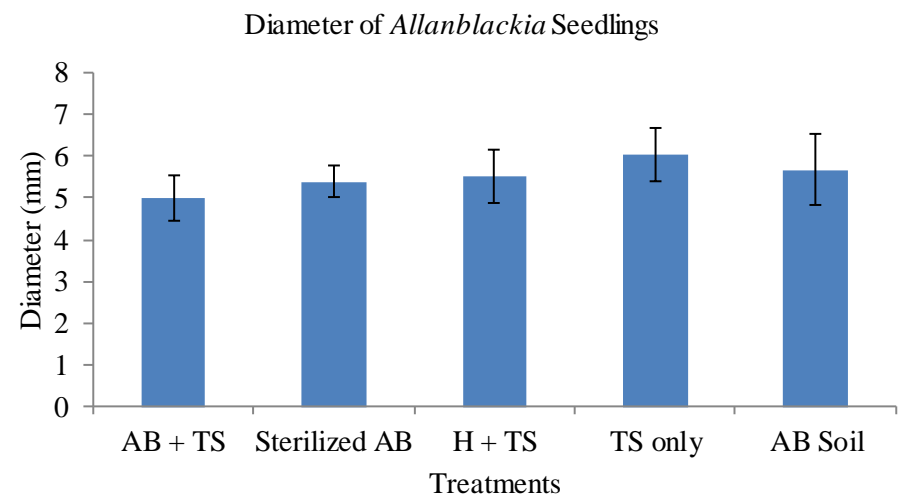

Figure 3. Diameter of Allanblackia seedlings as influenced by the growth media.

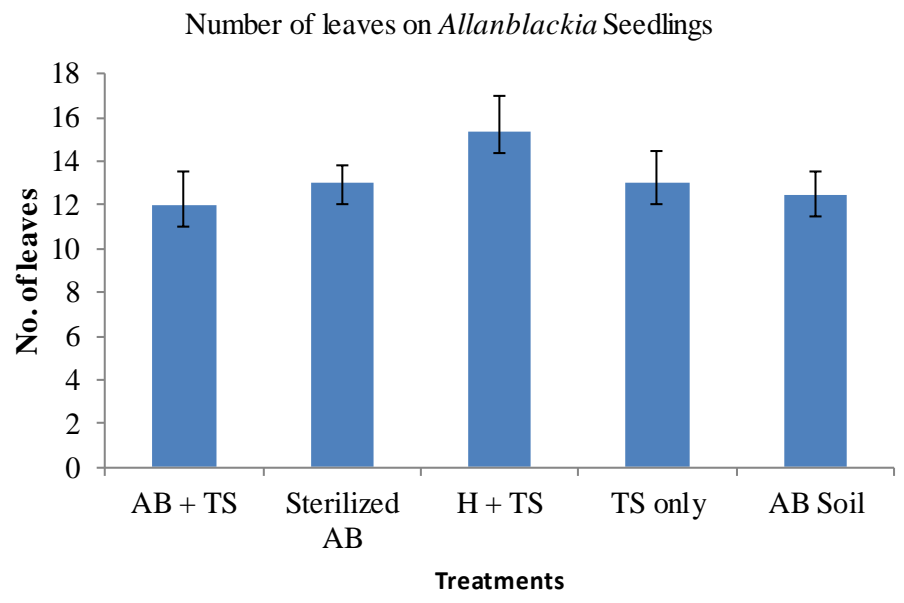

Figure 4. Effect of different media on leaf production of Allanblackia seedlings. 


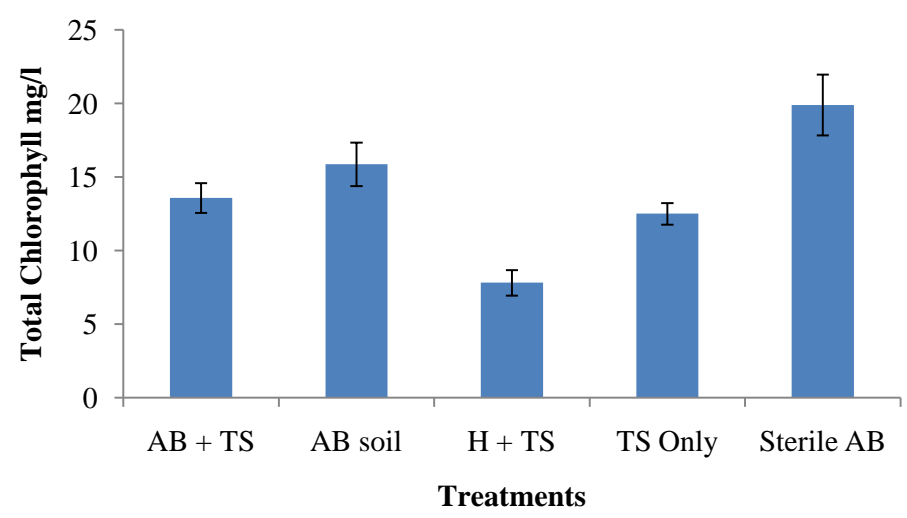

Figure 5. Effect of different growth media on chlorophyll content of Allanblackia seedlings.

parviflory. The growth parameters of Allanblackia parviflory were impacted differently by the growth media. The result was however controversial since no differences were found between growth of seedlings in streilized Allanblackia soil and Allanblackia soil. In future studies, factors affecting symbiotic microbe's efficiency need to be explored.

\section{References}

[1] Hawthorne, W. (1990) Field Guide to Forest Trees in Ghana. Chatham: Natural Resources Institute, for Overseas Development Administration, London. Ghana Forestry Series 1, 278.

[2] Hawthorne, W. and Gyakari, N. (2006) Photo Guide for Forest Tree of Ghana. A Tree Spotters Guide for Identification of Large Trees. Oxford Forestry Institute, UK, 432.

[3] Siaw, D.E.K.A., Cobbinah, J.R., Kankam, B.O., et al. (2003) Allanblackia floribunda. Final Report Submitted to Unilever Ghana Limited by Forestry Research Institute of Ghana, 69.

[4] Sefah, W. (2006) Extraction and Characterisation of Vegetable Fat from Allanblackia floribunda. Thesis Submitted to the Department of Biochemistry and Biotechnology in Partial Fulfilment of the Requirement for the Award of the Master of Science (M.Sc.) Degree in Food Science and Technology, Kwame Nkumah University of Science and Technology, 146.

[5] Ofori, D.A, Siaw, D.E.K.A, Peprah, T. and Cobbinah, J.R. (2006) Domestication of Allanblackia in Ghana. Progress Report (January-June 2006) Submitted to ICRAF, Nairobi, Kenya, 18.

[6] Irvine, F.R. (1961) Woody Plants of Ghana with Special Reference to Their Uses. Oxford University Press, London, 143-144.

[7] Leakey, R.R.B. (2001) Win-Win Land Use Strategies for Africa: 2. Capturing Economic and Environment Benefits with Multistrata Agroforests. International Forestry Review, 3, 331-340.

[8] Ofori, D.A., Peprah, T., Cobbinah, J.R., Atchwerebour, H.A., Osabutey, F., Tchoundjeu, Z., Simons, A.J. and Jamnadass, R. (2011) Germination Requirements of Allanblackia parviflora Seeds and Early Growth of Seedlings. New Forests, 41, 337-348. http://dx.doi.org/10.1007/s11056-011-9252-1

[9] Ofori, D.A., Peprah, T., Henneh, S., Von Berg, J.B., Tchoundjeu, Z., Jamnadass, R. and Simons, A.J. (2008) Utility of Grafting in Tree Domestication Programme with Special Reference to Allanblackia parviflora A. Chev. Ghana Journal of Forestry, 23\&24, 42-48.

[10] Peprah, T., Ofori, D. A., Siaw, D.E.K.A., Addo-Danso, S.D., Cobbinah, J.R., Simons, A.J. and Jamnadass, R. (2009) Reproductive Biology and Characterization of Allanblackia parviflora A. Chev. in Ghana. Genetic Resources and Crop Evolution, 56, 1037-1044. http://dx.doi.org/10.1007/s10722-009-9475-6

[11] Brown, K.R. and Van Den Driessche, R. (2005) Effects of Nitrogen and Phosphorus Fertilization on the Growth and Nutrition of Hybrid Poplars on Vancouver Island. New Forest, 29, 89-104. http://dx.doi.org/10.1007/s11056-004-5418-4

[12] Swift, M.J. (1998) Towards the Second Paradigm: Integrated Biological Management of Soil. FERTBIO Conference, Brazil, September 1998, 11-24.

[13] Brundrett, M.C., Bougher, N., Dell, B., Grove, T. and Malajczuk, N. (1996) Working with Mycorrhizas in Forestry and Agriculture. ACIAR Monograph, 32, 374 p. 
[14] Giri, B., Kapoor, R. and Mukerji, K.G. (2005) Effect of the Arbuscular Mycorrhizae Glomus and G. macrocarpum on the Growth and Nutrient Content of Cassia siamea in a Semi-Arid Indian wasteland Soil. New Forest, 29, 63-73.

[15] Sarr, A., Faye, A., Oihabi, A., Houeibib, A.J.O., Neyra, M. and Lesueur, D. (2005) Inoculation en station et au champ d'Acacia Senegal avec des souches selectionnées de rhizobium. Bois et Forêts des Tropiques, 283, 5-17.

[16] Onguene, N.A., Ngonkeu, L.E.M. and Kuyper, T.W. (2011) Growth Response of Pterocarpus soyauxii and Lophira alata Seedlings to Host Soil Mycorrhizal Inocula in Relation to Land Use Types. African Journal of Microbiology Research, 5, 2391-2398. http://dx.doi.org/10.5897/AJMR10.061

[17] Smith, S.E. and Read, D.J. (1997) Mycorrhizal Symbiosis. 2nd Edition, Academic Press, London, 605 p.

[18] McLean, E.O. (1982) Soil pH and Lime Requirement. In: Page, A.L. et al., Ed., Methods of Soil Analysis, Part 2, 2nd Edition, Agronomy Monograph 9.2, ASA and SSSA, Madison, WI, 119-224.

[19] Walkley, A. and Black, A. (1934) An Examination of the Degtjareff Methods for Determining Soil Organic Matter and a Proposed Modification of the Chromic Acid Titration Method. Soil Science, 37, 29-38. http://dx.doi.org/10.1097/00010694-193401000-00003

[20] Sims, J.T. (1996) Lime Requirement. In: Sparks, D., Ed., Methods of Soil Analysis. Part 3. Chemical Methods, SSSA Book Series No. 5, Soil Science Society of America and America Society of Agronomy, Madison, 491-515.

[21] Bray, R.H. and Kurtz, L.T. (1945) Determination of Total Organic and Available Forms of Phosphorus in Soils. Soil Science, 59, 39-45. http://dx.doi.org/10.1097/00010694-194501000-00006

[22] Payne, R.W., Harding, S.A., Murray, D.A., Soutar, D.M., Baird, D.B., Welham, S.J., Kane, A.F., Glimour, A.R., Thompson, R., Webster, R. and Tunnicliffe, W.G. (2006) The Guide to GenStat Release 9, Part 2: Statistics. VSN International, Oxford.

[23] Lal, R. (1983) Soil Erosion in the Humid Tropics with Particular Reference to Agricultural Land Development and Soil Management. International Association of Hydrological Sciences, 140, 221-239.

[24] Nye, P.H. and Stephens, D. (1962) Soil Fertility. In: Wills, J.B., Ed., Agriculture and Land Use in Ghana, Oxford University Press, London, 127-143.

[25] Plenchette, C., Furlan, V. and Fortin, J.A. (1983) Growth Response of Several Plant Species in a Soil of Moderate P-Fertility. I. Mycorrhizal Dependency under Field Conditions. Plant and Soil, 70, 199-209. http://dx.doi.org/10.1007/BF02374780

[26] Sieverding, E. (1991) Vesicular-Arbuscular Mycorrhiza Management in Tropical Agrosystems. GTZ n 224 FRG, 281 p.

[27] Ngonkeu, M.E.L. (2003) Biodiversité et potential des mycorhizes à arbuscules de vertaines zones agro-écologiques du Cameroun. Thèse de Doctorat 3ème cycle, Université de Yaoundé I Cameroun, 259 p.

[28] Ngonkeu, M.E.L. (2009) Tolérance de certaines variétés de maïs aux sols à toxicité aluminique et manganique du Cameroun et diversité moléculaire et fonctionnelle des mycorhizes à arbuscules. Thèse de Doctorat Ph.D. Université de Yaoundé I Cameroun, 224.

[29] Newman, E.I., Heap, A.J. and Lawley, R.A. (1981) Abundance of Mycorrhizas and Root-Surface Micro-Organisms of Plantago lanceolata in Relation to Soil and Vegetation: A Multivariate Approach. New Phytologist, 89, 95-108. http://dx.doi.org/10.1111/j.1469-8137.1981.tb04752.x

[30] Motosugi, H., Yamamoto, Y., Naruo, T., Kitabayashi, H. and Ishii, T. (2002) Comparison of the Growth and Leaf Mineral Concentrations between Three Grapevine Rootstocks and Their Corresponding Tetraploids Inoculated with an Arbuscular Mycorrhizal Fungus Gigaspora margarita. VITIS—Journal of Grapevine Research, 41, 21-25.

[31] Isaac, S. (1992) Fungal Plant Interactions. Chapman and Hall, London, 418.

[32] Tiessen, H., Cuevas, E. and Chacon, P. (1994) The Role of Soil Organic Matter in Sustaining Soil Fertility. Nature, 371, 783-785. http://dx.doi.org/10.1038/371783a0

[33] Zech, W., Guggengerger, G., Haumaier, L., Pohhacker, R., Schafer, D., Amelung, W., Miltner, A., Kaiser, K. and Ziegler, F. (1996) Organic Matter Dynamics in Forest Soils of Temperate and Tropical Ecosystems. In: Piccolo, R., Ed., Humic Substances in Terrestrial Ecosystems, Elsevier, Amsterdam, 101-170. 